\title{
PERANAN MEDICAL MINISTRY DALAM MENINGKATKAN MAKNA HIDUP (MEANING IN LIFE) PADA INDIVIDU DENGAN DISABILITAS FISIK KARENA KECELAKAAN (STUDI DI PANTI SOSIAL X)
}

\author{
Ade Lestari' ${ }^{1}$, Samsunuwijati Mar'at ${ }^{2}$, dan Sandi Kartasasmita ${ }^{3}$ \\ ${ }^{1}$ Fakultas Psikologi, Universitas Tarumanagara Jakarta \\ Email: ade.lestari08@gmail.com \\ ${ }^{2}$ Fakultas Psikologi, Universitas Tarumanagara Jakarta \\ Email: samsunuwiyatimarat@gmail.com \\ ${ }^{3}$ Fakultas Psikologi, Universitas Tarumanagara Jakarta \\ Email: seinama2003@yahoo.com
}

\begin{abstract}
ABSTRAK
Disabilitas yang disebabkan kecelakaan diyakini dapat memberikan pengalaman negatif bagi individu yang mengalaminya, berupa hilangnya semangat, rasa tidak berharga, bahkan keinginan untuk mengakhiri hidupnya di dunia. Namun dengan kondisi serupa, ditemukan ada contoh individu disabilitas yang tetap produktif, bahkan berprestasi. Penelitian ini bertujuan untuk mendapatkan gambaran apakah makna hidup menjadi kunci utama yang menyebabkan respon berbeda pada individu disabilitas. Menggunakan pendekatan medical ministry, individu disabilitas dibimbing untuk dapat menghayati pengalaman tragis yang tidak terhindarkan ini dengan memanfaatkan kemampuan mengambil sikap (attitudinal value) dan proses transedensi diri yang merupakan ciri khas dari penerapan metode medical ministry. Transedensi diri merupakan kemampuan untuk menyadari dan menilai keadaan "masa lalu dan saat ini", untuk kemudian mengaitkannya dengan sesuatu yang bermakna di "luar dirinya dan di masa depan". Desain penelitian menggunakan kuasi-eksperimen dengan tipe one group design dan mixmethod. Pemilihan sampel dilakukan tanpa memiliki probabilitas yang sama, melibatkan dua pria dan satu wanita, dengan kisaran usia 25-53 tahun, yang terdaftar sebagai Warga Binaan Sosial (WBS) di Panti Sosial Bina Daksa (PSBD) X yang berlokasi di Cengkareng. Hasil penelitian menunjukkan peningkatan 20-40 skor makna hidup yang diukur menggunakan Purpose in Life Test, dan seluruh subyek melaporkan perubahan perasaan positif, berupa rasa semangat menjalani kehidupannya, menilai diri berharga, dan keinginan mengembangkan diri untuk menjadi produktif.
\end{abstract}

Kata Kunci: Disabilitas, makna hidup, medical ministry

\section{PENDAHULUAN}

World Health Organization (WHO) memberikan definisi kesehatan sebagai kesatuan fisik, mental, dan kesejahteraan sosial. Saat ini, konsep kesehatan telah meluas dan dikaitkan dengan kualitas kehidupan individu (Ahmmad, 2014). Individu yang mengalami disabilitas karena kecelakaan pada masa dewasa, cenderung sukar menerima dan terus mempertanyakan pengalaman yang terjadi pada dirinya. Penemuan literatur menunjukkan bahwa kualitas kehidupan yang paling rendah dimiliki oleh individu dengan disabilitas cacat tubuh (Porvarðardóttir, 2014). Hal ini dapat disebabkan karena disabilitas cacat tubuh memberikan lebih banyak batasan aktivitas dan partisipasi (Porvarðardóttir, 2014; Schulz, 2005). Hassan (2010) mengungkapkan bahwa disabilitas dapat menyebabkan korban kehilangan makna hidup (meaning in life) dan attachment pada lingkungan sekitarnya.

Pandangan dan perilaku negatif terhadap disabilitas menghasilkan efek yang luas bagi penyandangnya, berupa rendahnya self-esteem dan penghindaran partisipasi sosial. Hal ini menghambat individu disabilitas dewasa (usia 19-60 tahun) dalam memenuhi tugas perkembangnnya yang sehat, yaitu menjadi mandiri, produktif, dan membangun hubungan 
berkualitas dengan pasangannya (intimacy). Ketidakmampuan individu dewasa memenuhi tugas perkembangannya dapat memberikan perasaan terisolasi, regresi dalam psikososial, dan ketidakmampuan menghadapi tahap perkembangan berikutnya (Feist, et al., 2013).

Pada Februari 2017, peneliti mendatangi sebuah panti sosial negara yang menyelenggarakan rehabilitasi bagi penyandang disabilitas tubuh yang disebut sebagai Warga Binaan Sosial (WBS). Berdasarkan hasil observasi, peneliti menemukan dua kondisi WBS yang berbeda, yaitu disabilitas produktif dan disabilitas tidak produktif. Produktivitas merujuk pada kemampuan individu untuk memperoleh manfaat yang sebesar-besarnya dari sarana dan prasarana yang tersedia dengan menghasilkan output yang optimal (Maryam, 2007). WBS yang terkategori produktif menunjukkan partisipasi aktif dalam mengikuti program keahlian yang diselenggarakan oleh panti. Sementara kondisi kedua adalah kelompok WBS disabilitas yang tidak produktif, sepanjang hari mereka hanya menonton televisi, berdiam diri, atau tidur. Mereka menunjukkan rendahnya minat untuk berinteraksi sosial, kesedihan, merasa kehidupan tidak bermakna, dan tidak memiliki harapan akan masa depan.

Merujuk pada teori yang disampaikan oleh Frankl, peneliti meyakini bahwa kondisi negatif dan tidak produktif ini dapat dijelaskan melalui teori kebermaknaan hidup (meaning in life). Frankl menyatakan bahwa kehidupan yang bermakna (meaningful life) adalah dasar dari produktivitas kerja (Bastaman, 2007). Kebermaknaan hidup dapat menuntun seseorang pada tujuan hidup yang jelas, hubungan antar pribadi yang akrab, kemantapan kepribadian, dan gerbang ke arah ketentraman dan kebahagiaan. Sementara, kegagalan dalam menemukan makna hidup dapat mempengaruhi interaksi individu dengan orang lain, menuntun pada psikopatologis berupa depresi, kecemasan, adiksi, agresi, ketidakberdayaan, apatis, rendahnya well-being, penyakit fisik, dan bahkan kemungkinan untuk melakukan tindakan bunuh diri (Glaw, 2016).

Medical ministry adalah sebuah intervensi psikologis yang kekhususannya ditujukan bagi individu yang mengalami kondisi tragis tak terhindarkan dan tidak dapat diubahkan lagi sekalipun upaya penanggulangan maksimal telah dilakukan, seperti kecacatan, kematian, dan penyakit terminal (Frankl, 1969; Bastaman, 2007). Medical ministry sebagai bagian dari logoterapi memiliki pandangan bahwa perjuangan untuk mendapatkan makna dalam kehidupan merupakan motivasi utama kekuatan seseorang yang akan menuntun pada kehidupan yang produktif, berharga, dan bahagia (happiness).

\section{Rumusan Masalah}

Apakah penerapan medical ministry dapat meningkatkan makna hidup (meaning in life) pada individu dengan disabilitas fisik karena kecelakaan? Peranan medical ministry dalam meningkatkan makna hidup ditunjukkan ketika terdapat peningkatan pada data post-test makna hidup.

\section{METODE PENELITIAN}

\section{Partisipan}

Partisipan dalam penelitian ini adalah tiga individu disabilitas fisik dengan kategori usia dewasa muda hingga madya (diatas 18 tahun) yang berada di sebuah panti sosial negara khusus disabilitas, mengalami disabilitas fisik yang disebabkan oleh kecelakaan minimal pada masa dewasa, dan tidak terkategori sebagai Orang Dengan Masalah Kejiwaan (ODMK). 


\section{Desain Penelitian}

Desain penelitian menggunakan kuasi-eksperimen dengan tipe one group pretest-postest design. Sementara, metode penelitian adalah mix-method, menggunakan kuesioner untuk mengukur kadar kebermaknaan hidup dan wawancara untuk menggali pandangan partisipan mengenai kebermaknaan dirinya sebelum dan setelah intervensi dilakukan.

\section{Setting Lokasi Penelitian}

Penelitian dilakukan di Panti Sosial Bina Daksa (PSBD) X yang berlokasi di Cengkareng. PSBD $\mathrm{X}$ adalah salah satu pelaksana teknis di lingkungan Dinas Sosial Pemerintah Provinsi DKI Jakarta, yang bergerak dalam bidang pemberian pelayanan rehabilitasi sosial kepada Warga Binaan Sosial (WBS) dengan disabilitas tubuh.

\section{Pengukuran}

Penelitian ini menggunakan alat ukur makna hidup Purpose in Life Test (PIL Test) yang dikembangkan oleh Crumbaugh \& Maholick berdasarkan Frankl's Questionnaire. PIL Test dirancang untuk memunculkan respon yang terkait dengan pengalaman seseorang terhadap tujuan dalam kehidupannya. PIL Test terdiri dari dua puluh butir pernyataan singkat dengan lima skala likert. Skor diperoleh dengan menjumlahkan respon jawaban subyek dengan skor minimal 20 dan skor maksimal 100.

\section{Prosedur}

Peneliti bekerja sama dengan pihak administrasi PSBD X melakukan seleksi partisipan, berupa tes kapasitas inteligensi Raven's Standard Progressive Matrices (SPM), tes kemampuan menalar Mini Mental State Examination (MMSE), dan kuesioner makna hidup Purpose in Life Test (PIL Test). Kemudian, partisipan diberikan intervensi menggunakan medical ministry sesuai dengan rancangan yang telah dibuat, disertai dengan observasi dan wawancara. Setelah program intervensi selesai diberikan, peneliti memberikan post-test (PIL Test) untuk menguji efektivitas intervensinya.

\section{HASIL PENELITIAN DAN PEMBAHASAN Subyek Pertama (AK)}

AK mendapatkan kebermaknaan hidupnya melalui serangkaian proses medical ministry (pretest: 63 ; post-test: 86). AK menghayati nilai bersikap sebagai sumber utama yang mengubahkannya (dilanjutkan dengan nilai penghayatan, berkarya, dan pengharapan). Ia mengaku bahwa kesadaran (awareness) membuatnya dapat bersikap lebih relaks dalam menjalani kehidupannya, dan mulai memacu dirinya sendiri untuk tidak terbatasi oleh situasi dan keadaan (nilai bersikap). Perubahan pandangan ini membuat AK menyikapinya dengan membuat rutinitasnya sendiri dan memilih untuk menghayati pengalaman kecelakaan dan diusir oleh keluarganya sebagai modal untuk menyemangati hidup WBS lain yang berada di panti (nilai penghayatan). Nilai penghayatan ini membuat AK tidak merasakan kejenuhan dan bosan seperti yang sebelumnya ia rasakan karena saat ini ia berpandangan bahwa setiap hari adalah pengalaman baru yang memiliki tantangan baru yang selalu menarik. AK pun menghayati makna hidupnya melalui sumber lainnya, yaitu nilai kreatif dan pengharapan. AK mengaku bahwa saat ini ia sudah dapat menemukan makna hidupnya, yaitu menjadi penyemangat bagi WBS lain yang berada di panti ini melalui kisah hidupnya. AK meyakini bahwa perubahan signifikan terjadi dalam dirinya, berupa menjadi lebih bersemangat pada setiap bangun tidur karena ia dapat memandang setiap hari merupakan kesempatan baru yang ia gunakan untuk menyemangati orang lain melalui kemampuannya berkomunikasi dan ingin menyalurkan kemampuan 
menggambarnya dalam keterampilan membatik (nilai kreatif) dan sembari terus berpengharapan bahwa akan ada kesempatan hidup yang lebih baik. AK bertekad untuk mendekatkan diri melalui kegiatan religius yang diyakininya (nilai pengharapan).

AK mengaku bahwa perilaku menangis yang sebelumnya terjadi sebanyak 4-5 kali dalam seminggu, saat ini sudah tidak ada lagi. AK mengatakan bahwa perbedaan signifikan yang ia rasakan adalah sebelumnya ia sering merasa bingung, sulit berkonsentrasi, dan tidak mampu menjawab pertanyaan mengenai makna hidupnya, namun saat ini, AK dapat dengan yakin dan berani menjawab tujuan hidupnya di dunia. saat ini, AK berpandangan bahwa ia harus memacu dirinya untuk berpandangan positif dan tidak mementingkan dirinya sendiri saja, ketika rasa sedih atau pikiran negatif muncul, AK dapat dengan lebih cepat menyadarinya dan mengalihkannya ke kegiatan produktif, seperti menggambar. AK pun mengatakan bahwa ketika ia sedang menyemangati orang lain dan menerima penolakkan, maka itu merupakan hal yang tidak merugikannya, sehingga tidak perlu membuatnya patah semangat. AK mengatakan bahwa perubahan ini dapat terjadi karena ia sudah mengubah sikapnya dalam menghayati pengalaman yang sebelumnya ia anggap sebagai sumber derita.

\section{Subyek Kedua (DS)}

DS mendapatkan kebermaknaan hidupnya melalui serangkaian proses medical ministry (pre-test: 40; post-test: 86). DS menghayati nilai bersikap sebagai sumber utama yang mengubahkannya (dilanjutkan dengan nilai penghayatan, pengharapan, dan berkarya). Ia mengaku bahwa kesadaran (awareness) membuatnya mampu memandang kehidupannya sebagai hal yang perlu diusahakan dan memilih untuk dapat menjalaninya dengan senang. DS menyadari bahwa dalam situasi terburukpun manusia tetap memiliki kendali untuk memilih tindakannya (nilai bersikap). DS mengaku bahwa ia memilih untuk mendekatkan diri kepada Tuhan melalui sholat dan melakukan perintahNya (nilai penghayatan) berupa melakukan kebaikan kepada orang lain, untuk menasihati dan berbagi pengalamannya agar orang lain tidak mengikuti jejaknya untuk bunuh diri, memberikan kue yang ia peroleh dari tamu panti kepada cleaning service panti, atau membelanjakan uang dari tamu panti untuk membeli kopi dan susu untuk dibagikan kepada teman-temannya (nilai kreatif), dan DS mengungkapkan harapannya untuk kehidupan yang lebih baik pada Tuhan (nilai pengharapan).

Perubahan signifikan yang dirasakan oleh DS adalah mengenai pandangannya bahwa kehidupan hanyalah untuk menunggu kematian menjemputnya. Saat ini DS berpandangan bahwa ia dapat hidup hingga saat ini merupakan hal yang berharga karena Tuhan masih memberikannya keselamatan dan kesadaran untuk bertobat. DS pun mengaku kepalanya yang sebelumnya terasa sangat berat dan penuh pikiran, saat ini menjadi lebih ringan dan fokus. Fokus ini membuatnya dapat memberikan nasihat kepada WBS lain yang sebelumnya ia abaikan. DS pun menyadari apabila perilakunya yang sebelumnya mementingkan diri sendiri tidak memberikan manfaat kepadanya, sehingga lebih baik ia gunakan untuk mendekatkan diri kepada Allah dan memberi masukkan kepada orang lain.

\section{Subyek Ketiga (NW)}

NW mendapatkan kebermaknaan hidupnya melalui serangkaian proses medical ministry (pretest: 68; post-test: 87). NW menghayati nilai bersikap sebagai sumber utama yang mengubahkannya (dilanjutkan dengan nilai penghayatan, pengharapan, dan kreatif). Ia mengaku bahwa kesadaran (awareness) membuatnya ingin meningkatkan dirinya agar dapat menghilangkan pandangan bahwa disabilitas membuat manusia tidak dapat melakukan apa-apa lagi (nilai bersikap). NW memandang kehidupannya saat ini sebagai sebuah pembelajaran yang 
diizinkan oleh Tuhan dan perlu diperjuangkan untuk menjadikannya berdampak positif bagi orang lain di sekitarnya (nilai penghayatan). NW meyakini bahwa tujuan hidupnya adalah menunjukkan perilaku yang terus bersemangat belajar keterampilan untuk mewujudkan impiannya dapat memiliki usaha mandiri di luar panti (nilai pengharapan), dapat menjadi cambuk bagi WBS lain yang lebih muda darinya namun bersikap putus asa. NW meyakini bahwa kehidupannya bermakna ketika ia dapat memiliki nilai kreatif, yaitu menghasilkan karya untuk orang lain.

Perubahan signifikan yang NW miliki adalah ketika sebelumnya ia dapat mendisiplinkan dirinya untuk terus berkegiatan namun sebenarnya ia merasa kosong, hampa, dan putus asa. Saat ini, NW tetap melakukan kegiatan yang sama, namun dengan pandangan baru yaitu memiliki tujuan bahwa setiap perilakunya dapat menjadikan pembelajaran bagi orang lain di sekitarnya. NW pun dengan yakin menyatakan bahwa ia sudah memiliki program pribadi untuk melakukan perbuatan baik kepada siapapun, dengan langkah awal mengubah sikap diri sendiri untuk tidak terus mengkritisi orang lain atau kondisi yang menghambatnya (nilai bersikap). Kini, ia dapat menerima apabila janji modal usaha tidak diturunkan, maka ia akan mencari cara lain untuk dapat mewujudkan impiannya dengan misalnya meminta karyanya di publikasikan ke luar, dan ia kerjakan dari ruang ketrampilan saja, atau meminjam sebuah kios di pasar terdekat panti dan membiarkan kios tersebut membawa nama panti, NW hanya berharap dapat melakukan kegiatan di tengah masyarakat.

\section{SIMPULAN DAN SARAN}

\section{Simpulan}

Berdasarkan analisis data yang telah dilakukan dengan membandingkan pre-test dan post-test, maka diperoleh peningkatan skor makna hidup (meaning in life) pada seluruh subyek setelah melalui empat sesi intervensi yang dilakukan secara intensif. Melalui kuesioner makna hidup, diperoleh skor pre-test AK, DS, dan NW adalah 63, 40, 68 yang kemudian mengalami peningkatan pada post-test menjadi 87, 86, 86. Peningkatan makna hidup nampak pada perubahan perasaan yang dilaporkan oleh ketiga subyek melalui data kualitatif pre-test, berupa subyek mengalami kehampaan dalam hidup, putus asa, rutinitas yang terasa membosankan, ketidakberhargaan, keinginan untuk mengakhiri hidup, dan produktivitas yang terhambat karena tidak merasakan semangat. Sementara data post-test memberikan kesaksian pengalaman subyek yang positif akibat dari kesadaran (awareness) yang telah dimilikinya, berupa keyakinan akan tujuan dari kehidupannya, perasaan mensyukuri kondisi dan kehidupannya saat ini, keberhargaan diri, bersemangat, perubahan fokus pada diri sendiri menjadi kepada orang lain, dan perilaku produktif sebagai tanggung jawab mereka atas kehidupan yang dipandang sebagai anugerah dari Tuhan. Berdasarkan penelitian ini dapat disimpulkan bahwa medical ministry berperan dalam meningkatkan makna hidup (meaning in life) pada individu dengan disabilitas fisik karena kecelakaan di PSBD X.

\section{Diskusi}

Seluruh partisipan melaporkan perasaan bahagia, berarti, dan berguna sekalipun dalam kondisi yang tidak menyenangkan. Perubahan penghayatan memberikan dampak positif perubahan perilaku keseharian subyek, oleh karenanya medical ministry dapat menjadi alternatif intervensi yang potensial.

Penelitian ini menyimpulkan bahwa sesungguhnya keempat nilai makna hidup merupakan satu kesatuan yang diperlukan oleh individu guna mewujudkan makna hidupnya, namun dengan urutan prioritas yang dihayati berbeda oleh masing-masing individu. 
Hasil penelitian memberikan dukungan pada pemaparan teori Frankl (1959) bahwa medical ministry telah tepat memfokuskan pendekatannya melalui nilai bersikap dan transedensi diri (self-trancendence). Langkah medical ministry dinilai bermanfaat dalam mewujudkan kesadaran (awareness) subyek untuk mengubah pengalamannya saat ini menjadi pengalaman yang diidealkannya.

Pelaksanaan pre-test dan post-test menggunakan PIL Test disarankan untuk dilakukan secara personal melalui wawancara. Penyesuaian pertanyaan menggunakan bahasa sederhana sangat disarankan untuk menghindari bias pada partisipan dengan pendidikan rendah.

\section{Saran}

Konstruk makna hidup bukanlah konstruk sederhana yang dapat dengan mudah dipahami oleh individu awam. Oleh karenanya, penelitian yang berfokus pada konstruk ini diharapkan dapat menerjemahkannya ke dalam bahasa sederhana berdasarkan kapasitas inteligensi subyek dan melakukan pemeriksaan berdasarkan kualitatif, sehingga penghayatan yang dimiliki subyek dapat tergali dengan maksimal dibandingkan hanya berpatokan pada skor kualitatif. Konstruk makna hidup merupakan konstruk yang kaya dan menarik untuk dapat diteliti lebih mendalam pada berbagai area kehidupan manusia. Pemahaman individu mengenai makna hidupnya dapat berdampak luas terhadap well being, kebahagiaan, hingga kepuasan hidup. Oleh karenanya medical ministry berpotensi untuk diujikan pada latar kasus berbeda seperti penyakit terminal atau tahanan dengan vonis ekstrem. Selain itu, berbagai metode logoterapi lainnya, berupa paradoxical intention, dereflection, atau existential analysis juga potensial untuk diujikan.

Saran kepada masyarakat diberikan untuk memberikan pemahaman dan pembelajaran bahwa disabilitas bukanlah penghambat bagi seseorang untuk dapat berfungsi maksimal dalam menjalani kehidupannya. Penghayatan makna hidup dapat menginspirasi masyarakat yang memiliki kerabat disabilitas untuk tidak berputus asa. Medical ministry dapat dijadikan sebagai alternatif solusi untuk meningkatkan kualitas kehidupan kaum disabilitas.

Saran kepada pemerintah diberikan untuk mempertimbangkan medical ministry sebagai alternatif terapi yang dapat diberikan untuk meningkatkan kualitas hidup kaum disabilitas maupun kelompok masyarakat luas lainnya. Fokus pemerintah untuk memperbaiki respon sosial terhadap kelompok disabilitas merupakan langkah tepat untuk memberikan perubahan positif dalam jangka panjang, sementara proses tersebut berlangsung, penerapan medical ministry untuk memperkuat individu disabilitas dapat dipertimbangkan sebagai solusi yang melengkapi tujuan utama tersebut. Perbaikkan yang dilakukan terhadap dua sisi, yaitu pada respon sosial dan respon individu disabilitas itu sendiri memberikan sumbangsih positif bagi negara, yaitu peningkatan kualitas hidup WBS disabilitas dan produktivitasnya.

\section{Ucapan Terima Kasih (Acknowledgement)}

Ucapan terima kasih kepada partisipan yang telah bersedia untuk melakukan proses wawancara. Terima kasih kepada pihak panti asuhan yang bersedia menjadi objek penelitian. Peneliti juga ingin mengucapkan terima kasih kepada pihak-pihak yang terlibat dalam peneletian ini. Terima kasih juga untuk pihak Universitas yang telah mendukung penelitian ini. 


\section{REFERENSI}

Ahmmad, M. R. \& Islam, M. N. (2014). Impact of disability on quality of life of urban disabled people in Bangladesh. International Journal of u-and e-Service, Science, and Technology, 7(4), 227-238. doi: 10.1007/s12207-010-9086-8

Bastaman, H. D. (2007). Logoterapi: Psikologi untuk menemukan makna hidup dan meraih hidup bermakna. Jakarta: Raja Grafindo Persada.

Bastaman, H. D. (2017, April). Logoterapi: Viktor Frankl. Seminar diadakan oleh Institut Psikoterapi Indonesia, Bintaro.

Bronk, K. C. (2014). Purpose in life: A critical component of optimal youth development. New York: Springer Dordrecht Heidelberg. Doi:10.1007/978-94-007-7491-9

Crumbaugh, J. C., \& Maholick, L. T. (1964). An experimental study in existentialism: The psychometric approach to Frankl's concept of noogenic neurosis. Journal of Clinical Psychology, 20, 200-207. doi:10.1002/1097-4679

Crumbaugh, J. C., \& Maholick, L. T. (1981). Manual of instructions for the purpose in life test. Murfeesboro, TN: Psychometric Affiliates.

Feist, J., Feist, G. J., \& Roberts, T.A. (2013). Theories of Personality ( $8^{\text {th }}$ ed). New York, NY: McGraw-Hill.

Frankl, V.E. (1959). Man's search for meaning. New York, NY: Pocket Books.

Frankl, V. E. (1969). The will of meaning: Foundation and applications of logotherapy. New York, NY: Meridian.

Glaw, X., Kable, A., \& Inder, K. (2016). Meaning in life and meaning of life in mental health care: An integrative literature review. Issues in Mental Health Nursing, 37(7), 1-13.

Hallford, D. J., Mellor, D., Cummins, R. A., \& McCabe, M. P. (2016). Meaning in life in earlier and later older-adulthood: Confirmatory factor analysis and correlates of the meaning in life questionnaire. Journal of Applied Gerontology, 1-25. doi: $10.1177 / 0733464816658750$

Hassan, A. H. (2010). Road traffic accidents among youth worldwide. UCQ Nursing Journal of Academic Writing, diambil dari http://www.ucalgary.edu.qa/files/ROAD\%20TRAFFIC\%20ACCIDENTS\%20AMONG \%20YOUTH\%20WORLDWIDE.pdf

Maryam. (2007). Hubungan antara masa kerja dan kebosanan dengan produktivitas kerja karyawan PT TOA-Galva Industries. Skripsi, Fakultas Psikologi Universitas Islam Negeri (UIN) Syarif Hidayatullah. Diambil dari http://repository.uinjkt.ac.id/dspace/bitstream/123456789/24503/1/MARYAM-PSI.pdf

Ningsih, E. R. (2014). Mainstreaming isu disabilitas di masyarakat dalam kegiatan penelitian maupun pengabdian pada masyarakat di STAIN Kudus. Jurnal Penelitian, 8(1), 71-92.

Schulenberg, S. E., Schnetzer, L. W., \& Buchanan, E. M. (2010). The purpose in life test-short form: Development and psychometric support. Journal of Happiness Study: Springer. doi:10.1007/s10902-010-9231-9

Schulz, E. K. (2005). The meaning of spirituality for individuals with disabilities. Disability and rehabilitation Journal, 27(21), 1283-1295.

Porvarðardóttir, E. (2014). Adolescents with physical disabilities and their wellbeing and peer relationships within secondary schools in Iceland (Thesis, Reykjavik Department of Psychology). Diambil dari http://skemman.is/stream/get/1946/19427/44365/1/BSc_ritger\%C3\%B0_pdf

WHO. (2011). Understanding disability. Diunduh pada tanggal 25 Februari 2017 dari http://www.who.int/disabilities/world_report/2011/en/ 